Tips om medisinsk litteratur, andre bøker, filmer og elektroniske medier som bør anmeldes, sendes tidsskriftet@legeforeningen.no

\section{Lege, polfarer og botaniker}

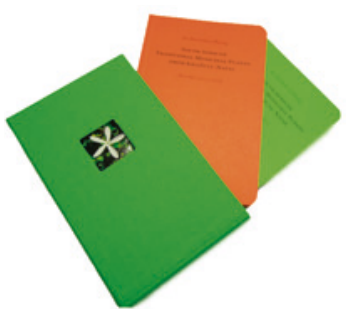

Berit Smestad Paulsen, Hege Ekeli,

Quinton Johnson, Kaare R. Norum

South African traditional medicinal plants from KwaZulu-Natal

Described 1903-1904 by dr. Henrik Greve

Blessing. 439 s, ill. To bøker i boks.

Oslo: Unipub, 2012. Pris NOK 449

ISBN 978-8-274775-76-3

Henrik Greve Blessing (1866-1916) var nyutdannet da han ble skipslege om bord på Fram under nordpolekspedisjonen 1893-1896. Hans innsats som polfarer har fått liten oppmerksomhet. Forklaringen kan være at han hadde få oppgaver, og at hans dagbok, som egentlig skulle tilhørt ekspedisjonen, ble bevart hos familien.

På Fram brukte Blessing selv morfinen i medisinkisten og ble narkoman. Dette førte til en livslang kamp mot misbruk. Han fikk mange nye sjanser og hadde god støtte, ikke minst fra Nansen, men verken nye stillinger, behandlinger eller forlovelse kunne hindre stadige tilbakefall. I et forsøk på å skape seg et nytt liv dro han i 1901 til Sør-Afrika, til en slektning som var misjonær i KwaZuluNatal. Der ville han arbeide som lege, men engelske styresmakter aksepterte ikke norsk medisinutdanning.

Han fant seg likevel til rette og skrev om landets historie og den pågående Boer-krigen. Etter et par år kunne han språket og kontaktet healere for å dokumentere bruken av medisinplanter.

Kunnskap om medisinplanter bygde på muntlig overlevering. Healerne fortalte hvordan plantene ble brukt, og hvor de vokste. Blessing hadde en vakker og leselig håndskrift og var flink til å tegne. Alt ble notert i to små notisbøker. Teksten er delvis på norsk, mens plantenavnene er på zulu.

Og så har notisbøkene ligget der i 100 år inntil en arving gjorde dem tilgjengelige. Bøkene er presentert for parlamentet i SørAfrika, hvor det er stor interesse for utvikling av plantemedisin.

Den røde boken er faksimile av notisbøkene. I den grønne boken har forfatterne funnet frem til og fotografert 95 av de 98 plantene.

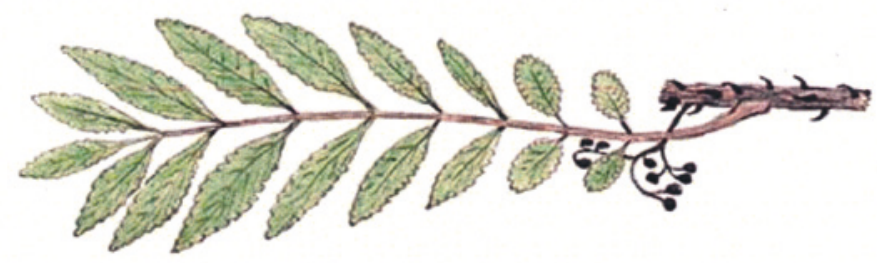

Eksempel på tegningene: Zanthoxylum capense. Gjengitt med tillatelse av Akademika forlag.

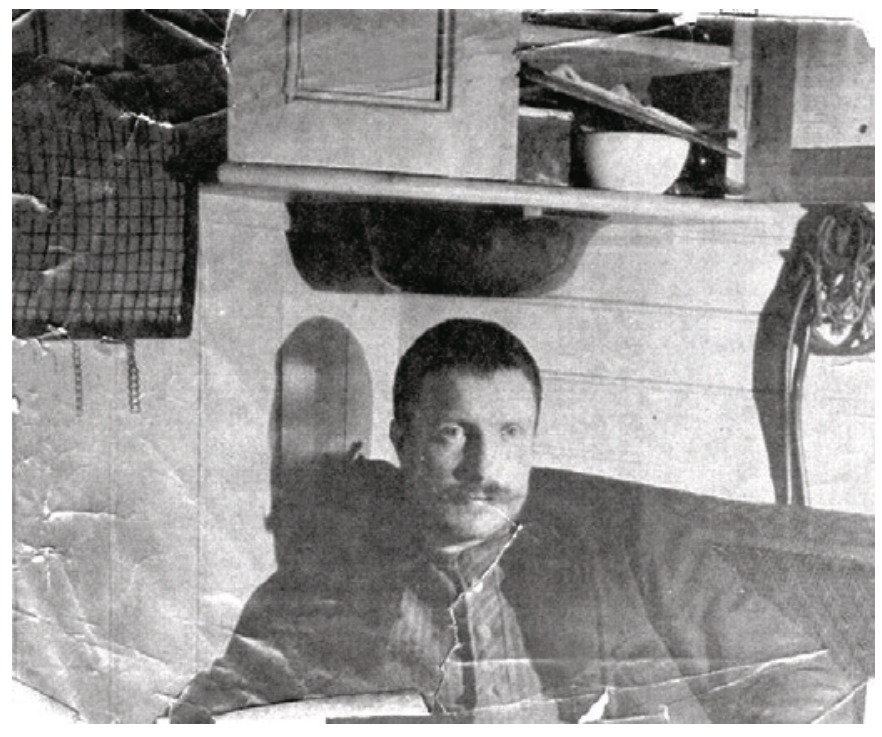

Henrik Greve Blessing om bord på Fram. Gjengitt med tillatelse av Akademika forlag.

Navnene er på zulu, engelsk og latin. En utskrift hjelper dem som ikke kan lese snirklete dansk-norske formuleringer. Forfatterne har også skrevet om tradisjonell bruk i dag og om vitenskapelig dokumentasjon.

Quinton Johnson på University of Stellenbosch skriver begeistret om fremtidig bruk av dokumentasjonen. Og det er grunn til begeistring. Dette er et tidsdokument over det som i noen grad hadde gått tapt, og gir tilbake kunnskap som har vært nedvurdert under kolonitid og apartheid. Bøkene representerer historie, kultur og medisin. Jeg anbefaler bokpakken særlig til dem med interesse for plantemedisin, og som reisefølge. Og kanskje blir dette kåret til årets vakreste bokverk!

\section{Signe Holta Ringertz \\ Oslo}

